\title{
Özel tip mısır genotiplerinin farklı gelişme dönemlerinde fizyolojik özellikler ile kalite özellikleri için heterosis, kalıtım derecesi ve gen etkilerinin incelenmesi
}

\author{
Investigation of heterosis, heritability and genetic effects for physiological and \\ quality traits in different developmental stages of specialty maize genotypes
}

\author{
Fatih KAHRIMAN $^{1}$, Cem Ömer EGESEL ${ }^{2}$ \\ ${ }^{1}$ Canakkale Onsekiz Mart Üniversitesi, Ziraat Fakültesi, Tarla Bitkileri Bölümü, Canakkale \\ ${ }^{2}$ Çanakkale Onsekiz Mart Üniversitesi, Ziraat Fakültesi, Tarımsal Biyoteknoloji Bölümü, Çanakkale \\ Sorumlu yazar (Corresponding author): F. Kahrıman, e-posta (e-mail): fkahriman@ hotmail.com
}

MAKALE BİLGİSİ

Alınıș tarihi 06 Nisan 2017

Düzeltilme tarihi 05 Eylül 2017

Kabul tarihi 05 Eylül 2017

\section{Anahtar Kelimeler:}

Genetik analizler

Dominans gen etkisi

Eklemeli gen etkisi

Varyasyon

\section{ÖZ}

Mısır bitkisi genetik araștırmalarda kullanılan en önemli model bitkilerden birisidir. Norma tane yapısına sahip mısır genotiplerinde çeşitli özelliklerin kalıtımını konu edinen çok sayıda araştırma bulunmasına karşın, özel tip mısır genotiplerinde bu araştırmalar sınırlı düzeyde kalmıștır. Bu çalıșma özel tip (yüksek yağlı, yüksek proteinli) mısır genotiplerinde bazı agronomik, fizyolojik ve kalite özelliklerinin kalıtımını konu edinmektedir. İki yıllık (2011 ve 2012) olarak yürütülen araştırmada ekimden itibaren 40., 60., 82., 100 ve 122. günlerde 13 agronomik, 9 fizyolojik ve 7 kalite özelliği olmak üzere toplam 29 özellik incelenmiştir. Elde edilen veriler Düzeltilmiş Sapmasız Hesaplama (Adjusted Unbiased Prediction) yöntemiyle eklemeli ve dominans model (Additive + Dominance) kullanılarak analiz edilmiștir. Her bir özellik için vejetasyon evrelerine göre heterosis, kalıtım dereceleri hesaplanarak bu hesaplamalardaki değișim incelenmiştir. Ayrıca heterosise neden olan gen etkileri polar grafik yöntemi ile gösterilmiştir. Araştırma bulguları heterosis ve kalıtım derecesinin vejetasyon süresinde özellik gruplarına göre değişim gösterdiğini ortaya koymuştur. Bitkisel özellikler ve fizyolojik özelliklerin büyük kısmında pozitif yönde ve yüksek derecede heterosis $(>\% 50)$ olduğu saptanmıştır. Tane protein, karbonhidrat ve yă̆ içeriğinde de bazı örnekleme tarihlerinde pozitif yönde heterosis olduğu belirlenmiștir. İncelenen özelliklerden 18'inde kalıtım derecesi yüksek bulunmuştur. Heterosise neden olan gen etkilerine ilişkin analizler, bitkisel özellikler ile fizyolojik özelliklerin çoğunda üstün dominans gen etkilerinin rol oynadığını, kalite özelliklerinde ise heterosisin dominant ve eklemeli gen etkileriyle ortaya çıktığını göstermiştir. Yüksek yağlı ve yüksek proteinli mısır genotipleri arasında bazı özellikler için heterosis ve kalıtım derecesi ile gen etki hesaplamalarında farklılıklar olduğ saptanmıştır. Ayrıca incelenen bazı özelliklerle ilgili heterosisin farklı gelişim evrelerinde değişim gösterdiği anlaşılmıştır.

\section{ARTICLE INFO}

Received 06 April 2017

Received in revised form 05 September 2017

Accepted 05 September 2017

Keywords:

Genetic analyses

Dominance gene effect

Additive gene effects

Variation

\section{ABSTRACT}

Maize is one of the most important model crops used in genetic research. Although there are numerous studies regarding the heritability of various traits in maize, such studies are rather limited on specialty maize genotypes. This study focuses on the heritability of some agronomic, physiological, and quality traits in specialty (high oil, high protein) maize. Data were collected on the $40^{\text {th }}, 60^{\text {th }}, 82^{\text {th }}, 100^{\text {th }}$, and $122^{\text {th }}$ days from the planting for 13 agronomic, 9 physiological, and 7 quality traits in a 2-year study (2011 and 2012). Additive + Dominance model of the Adjusted Unbiased Prediction method was utilized to analyze the data. For each trait, heterosis and heritability values were computed based on vegetative stages and the variation of these values were investigated. The gene effects inducing heterosis were shown with polar graphics. The results indicated that heterosis and heritability values varied based on trait groups during vegetation period. High $(>50 \%)$ and positive heterosis values were common for agronomic and physiological traits. Grain protein, carbohydrate and oil contents yielded positive heterosis for some sampling stages. The analyses of the gene effects causing heterosis showed that overdominance effects played a major role on agronomic and physiological traits, while the heterosis for quality traits were mainly under the control of dominance and additive gene effects. High oil and high protein maize genotypes had differences for heterosis, heritability and gene effect computations for some traits. It was understood that heterosis for some traits showed changes in different growth stages. 


\section{Giriş}

Heterosis, Shull tarafindan 1908 yılinda hibrit misirda deklare edildiğinden bu yana halen güncel ve çözülememiş bir konu olarak karşımızda durmaktadır. Heterosisin genetik nedenlerini açıklamak için farklı yaklaşımlar ve teoriler ortaya atılmıştır. $\mathrm{Bu}$ yaklaşımlar; dominans (dominance), tamamlayıcılık (complementation), üstün dominans (overdominance) ve sözde üstün dominans (pseudooverdominance) olarak bilinir (Veita ve Vaiman 2010). Yaygın kullanılan yönteme göre heterosis anaç ortalamalarına göre ve üstün anaca göre kıyaslamalar yapılarak hesaplanmaktadır. İstatistiki hesaplama ve tahminleme yöntemlerinin gelişmesi ile eklemeli-dominans modeller ile heterosis analizleri daha detayl hale getirilmiştir (Zhu 2003). İlk yaklaşımlarda her bir hibrite ait heterosis hesaplaması kendi ebevenyleri üzerinden yapıldı $\breve{g}_{1}$ için heterosis değerlerinin kıyaslanması pek bir şey ifade etmemektedir. Yeni genetik modellerde ise popülasyon genetiğine dayalı ve her bir genotipin popülasyona olan genetik etkisi üzerinden yapılan hesaplamalar kullanılarak heterosis belirlenmektedir. Bu nedenle elde edilen değerler birbirleri ile kıyaslanabilir hale gelmiştir. Daha karmaşı modellerde ise ana ve baba ebeveynlerin heterosise olan katkısını tespit etmek dahi mümkündür. Diğer taraftan heterosise neden olan gen etkisinin tipini ortaya koymak ve grafiksel yöntemler ile bunu göstermek amaciyla farklı grafiksel metotlar geliştirilmiştir (SwansonWagner ve ark. 2006). Yeni geliştirilen yöntemlerin birbirine göre avantaj ve dezavantajları bulunmasına karşın, eski yöntemlere göre önemli üstünlükleri vardır.

Islah çalışmalarında incelenen özellik üzerine genetik etkilerin bilinmesi ve bu genetik etkilerin birbirlerine olan oranları, ele alınan özelliği kontrol eden genlerin etki durumlarını belirlemek amacıyla kullanılmaktadır. Bitki 1slahında eklemeli, dominans ve epistatik gen etkileri ele alınan başlıca etkilerdir. Bir özelliğin değişimine hükmeden genetik etkilerin tespitinde bahsedilen genetik etkilerin birbilerine oranlarından faydalanılmaktadır (Gardner 1963).

Mısırda tane kalite özellikleri (Römisch-Margl ve ark. 2010), tarımsal özellikler, protein ve yağ oranı (Oliveira ve ark. 2006; Yusuf ve ark. 2009), tane verimi ve fizyolojik bazı özellikler (Tollenaar ve ark. 2004) için kullanılan hibrit kombinasyonların ebeveynlerine göre farkları değerlendirilmiştir. $\mathrm{Bu}$ çalışmalarda özellikle yă̆ oranının negatif yönde heterosise sahip olduğu, bazı kombinasyonların ise bu özellik bakımından pozitif yönde heterosis gösterdikleri saptanmıştır. Yüksek yağ ve yüksek proteinli mısır tiplerinde heterosis analizlerinin literatürde fazlaca yer bulmadığ 1 dikkat çekmektedir. Belirtilen literatür kaynaklarında kullanılan popülasyonların özelliklerine göre hesaplanan değerler de farklılık göstermiştir. Mısır ıslah setleri oluşturularak incelenen özellikler üzerine etkili olan genetik etki tipinin tespiti amacıyla farklı araştırmalar yapılmıştır. $\mathrm{Bu}$ araştırmalarda bitkisel özellikler ve kuru madde birikiminin dominans ve üstün dominans (Rood ve Major 1981), yağ oranının eklemeli, tane veriminin eklemeli ve dominans (Rosulj ve ark. 2002; Mittelmann ve ark. 2003), protein oranının ise eklemeli etkilerin yanı sıra kısmi dominans (Watto ve ark. 2009) gen etkilerinin kontrolünde olduğu rapor edilmiştir. Bu bulgulara karşın protein ve yağ oranının eklemeli olmayan (Shanthi ve ark. 2002) ve dominant gen etkilerinin (Orhun 2011) kontrolü ile değişim gösterdiğini bildiren araştırmalar da mevcuttur. $\mathrm{Bu}$ durum kullanılan popülasyonlar ve ıslah dizaynının gen etkilerinin tespitinde önemli bir etkiye sahip olduğunu göstermektedir. Heterosis, kalıtım derecesi ve genetik etki tipinin biyokimyasal özellikler başta olmak üzere bitkisel ve fizyolojik özelliklerde zamana bağlı değişimini inceleyen araştırma sayısı sınırlıdır. Vejetasyon süresince yapılan ölçümlere dayalı yapılacak hesaplamalarla heterotik genlerin fonksiyonel olarak etkin olduğu dönemler tespit edilebilir. $\mathrm{Bu}$ sayede 1slah çalışmalarında incelenen özelliklerde heterosis ve gen etki durumları dikkate alınarak farklı planlama ve düzenlemeler yapılabilir. Özellikle seleksiyon amaçlı araştırmalarda verim ya da kalite özelliklerine ilişkin gözlemlerin erken dönemde yapılabilmesi tek bitki seçiminde ve seçilen bitkilerin birbirleri ile tozlanarak eşleştirilmelerinde faydalı olabilir. Diğer taraftan özellikler üzerine etkili olan gen etkilerinin dönemlere göre değişim gösterip göstermediği dikkate alınarak 1slah araştırmalarına yönelik özel bazı önermelerde bulunulabilir. Özel tip misırlarda heterosis, kalitım derecesi ve gen etkilerindeki değişimin anlaşılması ile normal bir mısır genotipinin özel tip mısıra dönüştürülmesi amacıyla yürütülecek çalışmalarda kullanılabilecek temel fikirlerin elde edilmesi mümkün olabilir.

$\mathrm{Bu}$ çalışmanın başlıca amacı; yüksek yağlı ve yüksek proteinli mısır genotiplerinde ölçülen agronomik ve fizyolojik özelliklere ait heterosisin zamana ve genotiplere göre değişiminin incelenmesi, kalıtım derecelerinin tespiti, özelliklerin değişiminde rol oynayan ve heterosise neden olan gen etki tiplerinin tespit edilmesidir.

\section{Materyal ve Yöntem}

\subsection{Bitki Materyali ve Denemenin Organizasyonu}

$\mathrm{Bu}$ çalışmada dört ebeveyn ve bunlarla oluşturulan dört hibritten oluşan toplam sekiz genotiplik bir set materyal olarak kullanılmıştır. IHO ve IHP ebeveynleri Illinois Uzun Süreli Seleksiyon çalışmasının 70. nesilden üretilen kendilenmiş saf hatlardır. IHO yüksek yağlı ( \% 12), IHP ise yüksek proteinli ( \% 22) hattır. Diğer ebeveynler misırda Stiff Stalk ve Lancaster heterotik gruplarının önemli temsilcileri olan B73 ve Mo17 kendilenmiş saf hatlarıdır. Bu ebeveynlerden nitelikli olanlar ana, normal hatlar baba olarak kullanılarak 2010 yılında dört melez kombinasyon $(\mathrm{IHO} \times \mathrm{B} 73, \mathrm{IHO} \times \mathrm{Mo17}$, IHP $\times \mathrm{B} 73$, $\mathrm{IHP} \times \mathrm{Mo17}$ ) oluşturulmuştur.

Genotipler 2011 ve 2012 yıllarında ÇOMÜ Dardanos Araştırma ve Uygulama biriminde 3 tekerrürlü olarak tarla denemesine alınmıştır. Tesadüf blokları deneme desenine göre yürütülen denemede yıllara göre sıcaklık, yăğş̧ durumları ile deneme alanının toprak özellikleri ile ilgili genel bilgiler Çizelge 1'de sunulmuştur. Bitkilerin durumuna göre 7-10

Çizelge 1. Denemenin yürütüldüğü yıllarda genel iklimsel özellikler ile deneme alanının toprak özellikleri.

Table 1. Soil characteristics of the experimental area and general climatic characteristics during the years when the experiment was conducted.

\begin{tabular}{lll}
\hline & $\mathbf{2 0 1 1}$ & $\mathbf{2 0 1 2}$ \\
\hline Ortalama Sıcaklık & $22.3^{\circ} \mathrm{C}$ & $22.9^{\circ} \mathrm{C}$ \\
Min-Mak. Sicaklık & $5.5-35.14{ }^{\circ} \mathrm{C}$ & $7.8-37.3{ }^{\circ} \mathrm{C}$ \\
Toplam Yağış & $164.8 \mathrm{~mm}$ & $111.8 \mathrm{~mm}$ \\
$\mathrm{pH}$ & 7.93 & 7.82 \\
$\mathrm{EC}$ & $0.62 \mathrm{mS} \mathrm{cm}$ & $0.60 \mathrm{mS} \mathrm{cm}$ \\
Kireç & $11.1 \%$ & $13.7 \%$ \\
Org Madde & $1.26 \%$ & $1.28 \%$ \\
$\mathrm{P}$ & $38.2 \mathrm{~kg} \mathrm{ha}^{-1}$ & $37.4 \mathrm{~kg} \mathrm{ha}^{-1}$ \\
$\mathrm{~K}$ & $557.8 \mathrm{~kg} \mathrm{ha}^{-1}$ & $524.1 \mathrm{~kg} \mathrm{ha}^{-1}$ \\
\hline
\end{tabular}


günlük aralıklarla sulama yapılmış ve birinci yıl $420 \mathrm{~mm}$ ikinci y1l $417 \mathrm{~mm}$ su verilmiştir. Gübreleme işlemi toprak özellikleri dikkate alınarak $17 \mathrm{~kg} \mathrm{da}^{-1}$ saf azot hesabı ile gerçekleştirilmiştir.

\section{2. Örneklemelerin Yapılması ve Ölçümler}

Her y1lda ekim tarihinden itibaren 40. (ESG1), 60. (ESG2), 82. (ESG3), 100. (ESG4), ve 122. (ESG5) günlerde örnekleme ve ölçümler yapılmıştır. Bir genotip için her bir tekerrürde tesadüfî olarak seçilen 3'er adet bitki üzerinde bitkisel gözlemler yapılmıştır. Örnekleme yapılan bitkiler kontrollü tozlama esaslarına uygun olarak çoğaltılmıştır. Seçilen bitkilerin yapraklarından 10 adet yaprak diski alınarak klorofil a, klorofil $\mathrm{b}$ ve toplam klorofil içerikleri UV-VIS Spektrofotometre (PG Instruments, İngiltere) cihazında $645 \mathrm{~nm}$ ve $663 \mathrm{~nm}$ 'deki absorbans değerleri alınmak suretiyle Hiscox ve Israelstam (1979)'un belirttiği yönteme uygun şekilde tespit edilmiştir. Yaprak disklerinin alınmasının ardından seçilen bitkiler kök boğazından kesilerek organ bazında (yaprak, sap ve koçan) ağırlıkları alınmıştır. Yaprak alanını belirlemek amacıyla hasat sonrasında her bitki örneğine ait yapraklar masaüstü tarayıcıda taranmış ve bmp formatında kaydedilmiştir. Kaydedilen resimler CompuEye programına (Bakr 2005) aktarılarak örneklere ait toplam ve yeşil yaprak alanları belirlenmiştir. Elde edilen değerler toplam yaprak alanı, yaprak yeşil alanı, yaprak alan indeksi, yeşil yaprak alan indeksi ve yeşillik indeksi ile ilgili hesaplamaların yapılmasında kullanılmıştır. Bu ölçümlerin ardından tüm bitki kısımları $80^{\circ} \mathrm{C}$ 'de 72 saat süreyle kurutulmuş ve kuru madde içerikleri belirlenmiştir (Wyss ve ark. 1991).

Kurutma sonrasında örnekler öğütülmüş ve protein, yağ ve karbonhidrat oranlarının tespiti için NIR ölçümleri yapılmıştır. Ögütme işleminde sap ve yapraklar ile tane örnekleri $0,5 \mathrm{~mm}$ elek çapında laboratuvar tipi değirmenlerde (Retsch, Fritsch, Almanya) ögütülmüştür. Öğütme sonrasında örnekler NIR specktroskopi (Spectrastar 2400D, Unity Scientific, Amerika) cihazında analiz edilmiştir. Analizlerde 1200-2400 nm arasında her bir nm'de spektrumlar alınmış ve yaprak sap örnekleri için Grass Silage and Forage kalibrasyon modeli, tane örnekleri için ise lokal bir kalibrasyon modeli kullanılarak örneklerin protein, karbonhidrat ve yağ içerikleri tespit edilmiştir.

\subsection{Istatistik Analizler}

\subsubsection{Genetik model}

Genetik analizlerde Zhu (2003) tarafindan önerilen eklemeli-dominans model (Model 3) kullanılmıștır. Bu model her bir gözlem tarihinde alınan verilere ayrı ayrı uygulanmıştır. Tahminleme yöntemi olarak AUP (Adjusted Unbiased Prediction) ve MINQUE1 (Minimum Quadritic Unbiased Estimation) metodları kullanılmış, blok etkisi modele dâhil edilmiş ve Jacknife prosedüründe hücre değeri 1 alınmıştır. İncelenen özellikler ile ilgili eklemeli ve dominans etkilerin hesaplanması için aşağıdaki istatistik modelden faydalanılmıştır:

\section{Model 1:}

$$
\mathrm{Y}_{\mathrm{hijk}}=\mu+\mathrm{E}_{\mathrm{h}}+\mathrm{G}_{\mathrm{i}}+\mathrm{GE}_{\mathrm{hij}}+\mathrm{B}_{\mathrm{hk}}+\mathrm{e}_{\mathrm{hijk}}
$$

Burada; $Y_{\text {hijk}}$ : gözlemlenen değer, $\mu$ : genel ortalama, $E_{h}$ : y1l etkisi $h(h=1,2), G_{i}$ : genotip etkisi i $(i=1,2, \ldots 8), G_{h i j}$ : y1l $\times$ genotip interaksiyon etkisi, $\mathrm{B}_{\mathrm{hk}}$ : h. yılda $\mathrm{k}$. tekerrürün etkisi $(\mathrm{k}=1,2,3 ; \mathrm{h}=1,2), \mathrm{e}_{\mathrm{hijk}}$ : tesadüfi hata olarak tanımlanmıştır.

\subsubsection{Heterosis analizi}

Heterosis analizlerinde yine Zhu (2003) tarafindan önerilen aşağıdaki formüller kullanılmıştır.

Herhangi bir melez kombinasyonu (Fn) için anaç ortalamalarına göre (HM) heterosis hesaplanmıştır. Anaç ortalamalarına göre genel heterosis; $\operatorname{HM}(F n)=(1 / 2) n-1 \Delta D$, anaç ortalamalarına göre interaksiyon heterosis; $\operatorname{HME}(\mathrm{Fn})=(1 / 2) n$ $1 \triangle \mathrm{DE}$ formüllerine göre hesaplanmıştır. Heterosis analizlerinde kullanılan formüllerde $\Delta \mathrm{D}$ : dominans heterosisi, $\triangle \mathrm{DE}$ : $\mathrm{DE}$ interaksiyon heterosisi, $\omega \mathrm{G}$ : ebeveynlerin genotipik farkını, $\omega \mathrm{GE}$ : ebeveynlerin interaksiyon etkisine bağlı farkını göstermektedir (Zhu 2003). Heterosis değerlerinin önem testleri tek yönlü $t$ testi kullanılarak yapılmıştır. Heterosis analizleri QGAStation V.2 programında gerçekleştirilmiştir (Chen ve ark. 2012).

\subsubsection{Kalttım derecelerinin tahmini}

İncelenen özelliklere ait kalıtım derecelerinin tespitinde Zhu (2003) tarafindan önerilen varyans modelinde hesaplanan varyans bileşenleri kullanılmıştır. Bu bileşenlerin tespiti için AUP (Adjusted Unbiased Prediction) yöntemi kullanılmış ve tahminleme yöntemi olarak MINQUE1 (Minimum Norm Quadritic Unbiased Estimate) metodundan faydalanılmıştır. Geniş anlamda kalıtım derecesi $(\mathrm{H})$, dar anlamda kalıtım derecesi $\left(\mathrm{h}^{2}\right)$, çevreye bağlı geniş anlamda kalıtım derecesi (HE) ve çevreye bağlı dar anlamda kalıtım derecesi $\left(h^{2} E\right)$ fenotipik varyans içerisinde genetik etkilerin payları olarak hesaplanmıştır. Kalıtım derecelerinin tahmini QGAStation V.2 programında gerçekleştirilmiştir (Chen ve ark. 2012).

\subsubsection{Gen etkilerinin gösterimi}

İncelenen özelliklerdeki değişime etkili olan genlerin etki durumlarını belirlemek ve görsel olarak sunmak amacıyla Swanson-Wagner ve ark. (2006) tarafindan geliştirilen metoda göre oluşturulan polar grafik yönteminden yararlanılmıştır (Lisec ve ark. 2011). Bu grafiklerde gen etkisinin tipi 360 derecelik bir dairesel grafik üzerinde hibritler ve ebeveynlere ait tekerrür ortalamaları kullanılarak gösterilmiştir. Ölçülen değerlere dayalı olarak her bir melezin anaçlarından farkı belirlenmiştir. Bu fark değerleri önce dereceye daha sonra da radyana dönüştürülerek genotipler arasındaki ayrım daha net hale getirilmeye çalışılmıştır. Polar grafikler PolarPlot kodları (Lisec ve ark. 2011) kullanılarak R.2.12 programında oluşturulmuştur (R Development Core Team 2012).

\section{Bulgular ve Tartışma}

\subsection{Heterosis Analizleri}

İncelenen özellik gruplarına göre heterosis değerlerinin örnekleme tarihlerine ve genotiplere göre değişimi Şekil 1, Şekil 2 ve Şekil 3'te sunulmuştur.

Örneklem tarihleri dikkate alındığında bitkisel özelliklerden bitki boyu ile yaş ve kuru ağırlıkların tamamında pozitif yönde heterosis gözlenmiştir. Genotipler dikkate alındığında ise IHP ile oluşturulan hibritlerin IHO hibritlerine göre nispeten daha yüksek heterosis değerlerine sahip oldukları görülmektedir (Şekil 1). Yaprak, sap, tane ve koçan nem oranlarında gözlemlenen heterosisin ise çok düşük veya negatif yönde olduğu dikkat çekmiş̧tir (Şekil 1). 


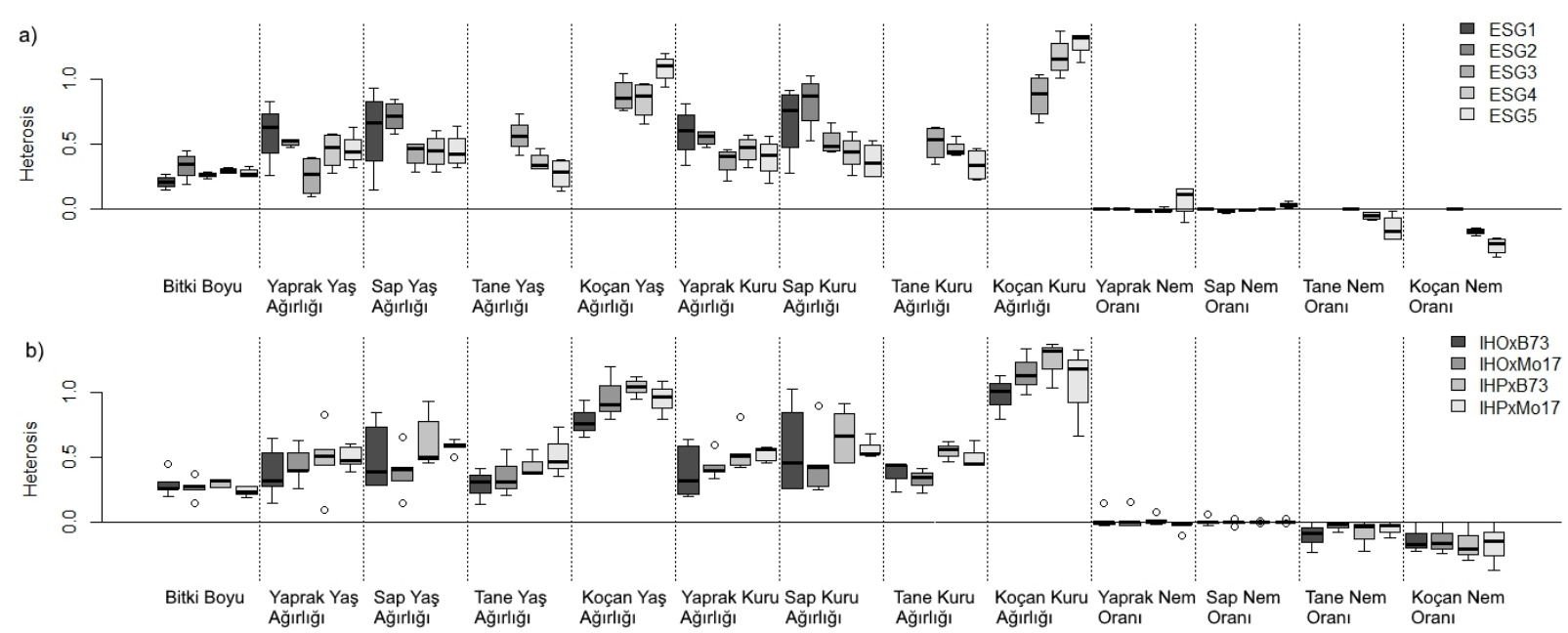

Şekil 1. ESG (a) ve hibritlere (b) göre bitkisel özellikler için heterosis değerleri.

Figure 1. Heterosis values for plant traits for ESG (a) and hybrids (b).

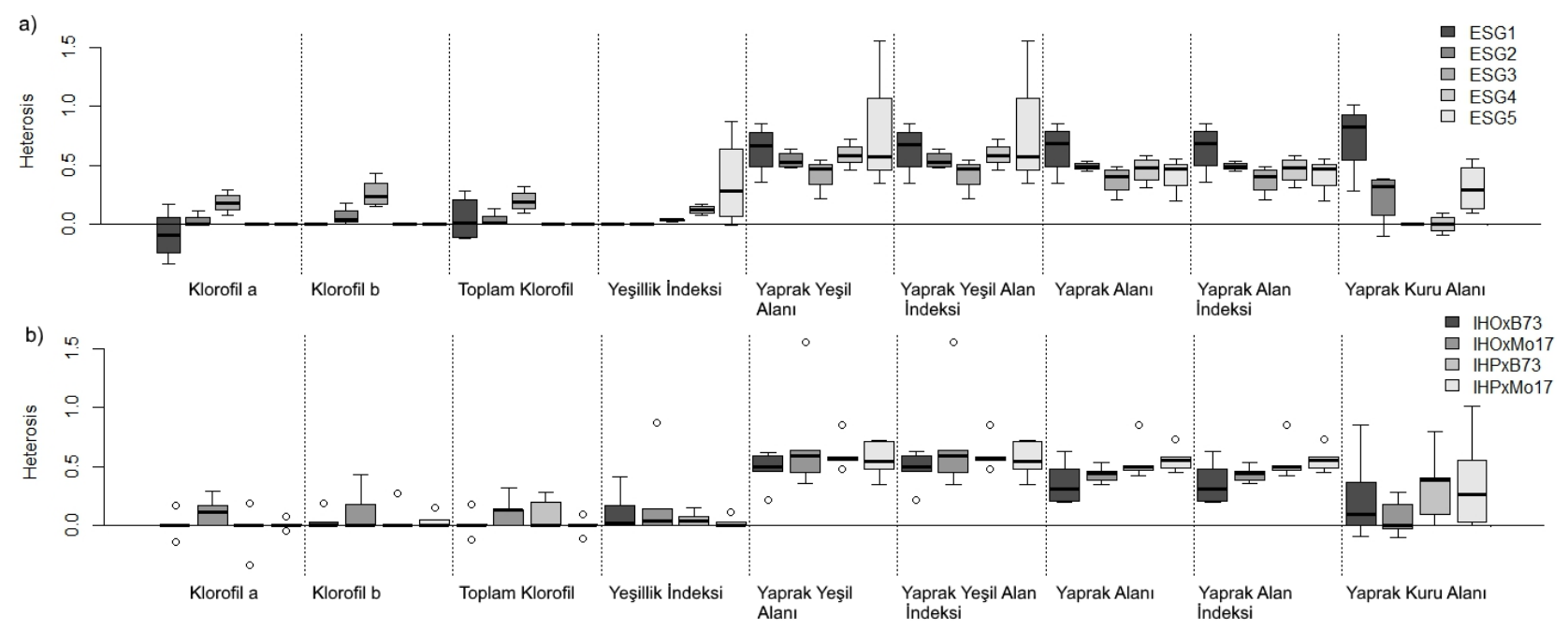

Şekil 2. ESG (a) ve hibritlere (b) göre fizyolojik özellikler için heterosis değerleri.

Figure 2. Heterosis values for physiological traits for ESG (a) and hybrids (b).

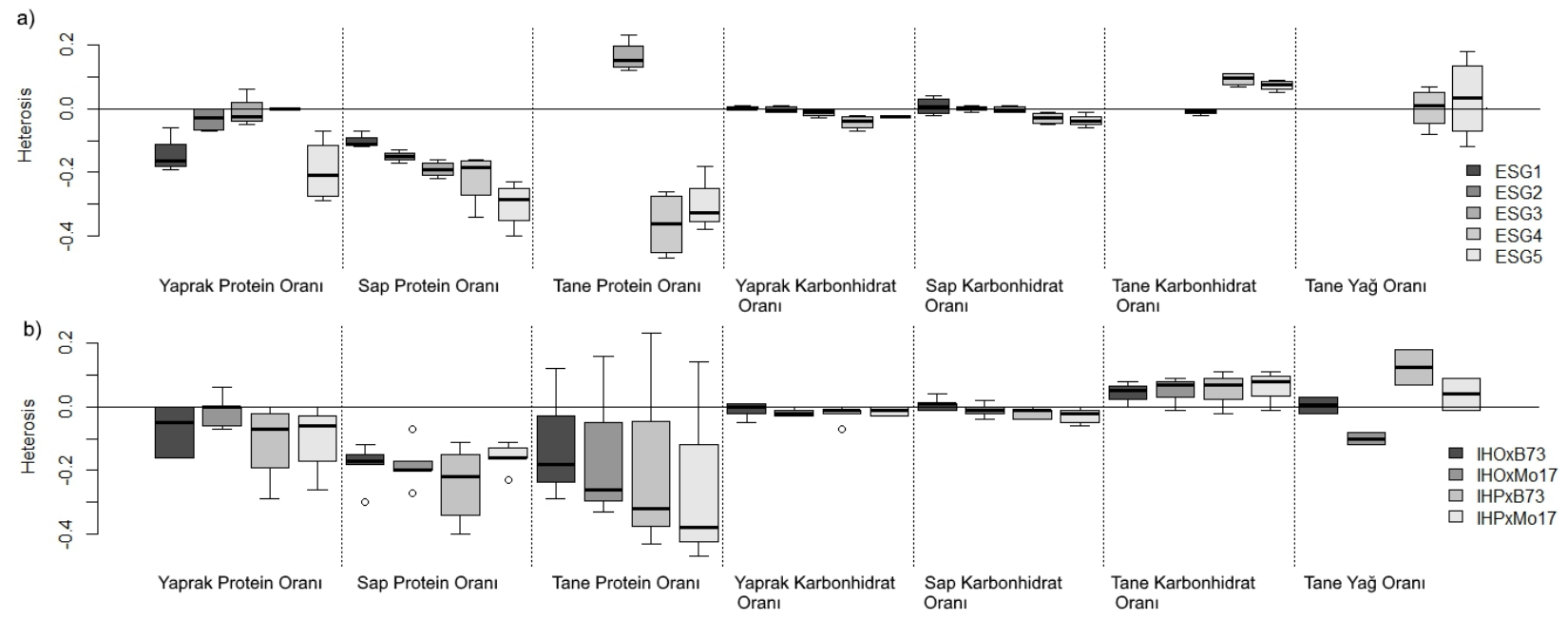

Şekil 3. ESG ve hibritlere göre kalite özellikleri için heterosis değerleri.

Figure 3. Heterosis values for quality traits for ESG (a) and hybrids (b). 
Fizyolojik gözlemlerden klorofil içerikleri için yalnızca ekimin ardından 82. günde yapılan örneklemelerde heterosis değerleri önemli bulunmuştur. $\mathrm{Bu}$ bulgular heterosisin ele alındığı çalışmalarda, ilgili özellikler için hangi dönemlerde incelemelerin yapılabileceğini ortaya koymuştur. Yaprak alanı ve yaprak alan indeksine ait heterosis değerlerinin vejetatif gelişim ilerledikçe düştüğü görülmüştür. Hesaplanan heterosis değerleri bakımından yüksek yağlı ve yüksek proteinli hibritler arasında önemli farklar tespit edilmiştir. Yaprak alanı ve yaprak alan indeksi için IHP melezlerinin IHO melezlerine heterosis değerleri bakımından üstünlük sağladığı görülmektedir (Şekil 2). Bununla birlikte $\mathrm{IHO} \times \mathrm{B} 73$ melezinde yaprak yeşil alanı, yaprak yeşil alan indeksi, yaprak alanı ve yaprak alan indeksi için hesaplanan heterosis değerlerindeki değişkenlik diğer hibritlerden yüksek bulunmuştur (Şekil 2). Bitkisel özellikler üzerine heterosis gözlemleri yapılan önceki çalışmalarda da bitki boyu ve yaprak alanı gibi özelliklerde pozitif heterosis olduğu tespit edilmiştir (Mahmood ve ark. 2016). Pozitif yönde heterosis tespit edilen bitki boyu gibi özelliklerde üstün dominans gen etkilerinin ve farklı lokuslardaki dominant veya epistatik allelerin etkisiyle heterosisin ortaya çıktığ 1 vurgulanmıştır (Hallauer ve Miranda 1981). Bu konuda çalışmamızda heterosise neden olan gen etkilerini göstermek amaciyla yapilan analizler söz konusu bulguyu desteklemektedir.

Kalite özelliklerine ilişkin heterosis analizi sonuçları yaprak, sap ve tane protein oranının negatif yönde heterosis değerlerine sahip olduğunu göstermiştir. Tane karbonhidrat oranı ve tane yağ oranında pozitif yönde heterosis gözlemlenmiştir (Şekil 3). Kalite özellikleri ile ilgili heterosis analizi sonuçlarında dikkat çeken hususlar şunlardır: Sap protein oranına ait heterosis değerleri vejetasyonun ilerleyen evrelerinde devamlı düşüş göstermiştir. Yüksek proteinli hibritlerde tane yağ içeriği, yüksek yağlı hibritlerde ise tane protein içeriğine ilişkin heterosis değerleri diğerlerinden yüksek bulunmuştur. Yaprak, sap ve tane protein içeriğinde hesaplanan heterosis değerlerinin karbonhidrat içeriği ile ilgili değerlere göre daha yüksek değişime sahip olduğu dikkat çekmiştir (Şekil 3). Werle ve ark. (2014) 64 farklı hibrittte protein ve yağ oranı için heterosis durumunu değerlendirilmiş ve bu genotiplerden 4'ünde protein oranı için, 31'inde ise yağ oranı için pozitif yönde heterois olduğunu saptamışlardır. Bekele ve Rao (2013) protein ve yağ oranı bakımından 24 ayrı hibritte heterosis hesaplamaları yapmış ve kullanılan materyalin büyük kısmında bu özellikler için negatif yönde heterosis olduğunu belirlemişlerdir. $\mathrm{Bu}$ bulgulara dayanarak kullanılan materyale bağlı olarak kalite özelliklerinde heterosis değerlerinin değişebileceği söylenebilir. Diğer taraftan araştırmamızda yağ ve karbonhidrat oranı için pozitif yönde heterosis tespit edilmiş olmasının nedenlerinden birisi de kullanılan hesaplama yönteminin popülasyon ortalaması üzerinden yapılmış olması ve kullanılan ebeveynlerin nitelikli genotiplerden oluşmasıdır.

\subsection{Kalitım Dereceleri}

Çalışmada kalıtım derecelerinin genotipik olarak hesaplanması mümkün olmadığından, özelliklere göre geniş anlamda kalıtım derecesi $(H)$, dar anlamda kalıtım derecesi $\left(h^{2}\right)$, dar anlamda kalıtım derecesinin çevre ile interaksiyonu $\left(h^{2} \mathrm{E}\right)$ ve geniş anlamda kalıtım derecesinin çevre ile interaksiyonu (HE) değerleri hesaplanmıştır. Söz konusu hesaplamalar grafiksel olarak Şekil 4'te sunulmuştur.

Çalışmada bitkisel özelliklerden yaş ve kuru ağırlıklara ilişkin incelenen özelliklerin geniş anlamda kalıtım derecesinin yüksek $(>0.60)$ olduğu, hesaplanan diğer değerlerin ise düşük olduğu dikkat çekmektedir (Şekil 4a). Schön ve ark (1993) bitki boyu gibi özelliklerde kalıtım derecesinin oldukça yüksek olduğunu ( $\mathrm{h} 2>0.80)$ bildirmiştir. Araştırmamızda elde edilen sonuçlar bu bulguları destekler niteliktedir. Yaprak, sap ve tane nem oranında ise hesaplanan kalıtım derecelerinin çevre ile olan
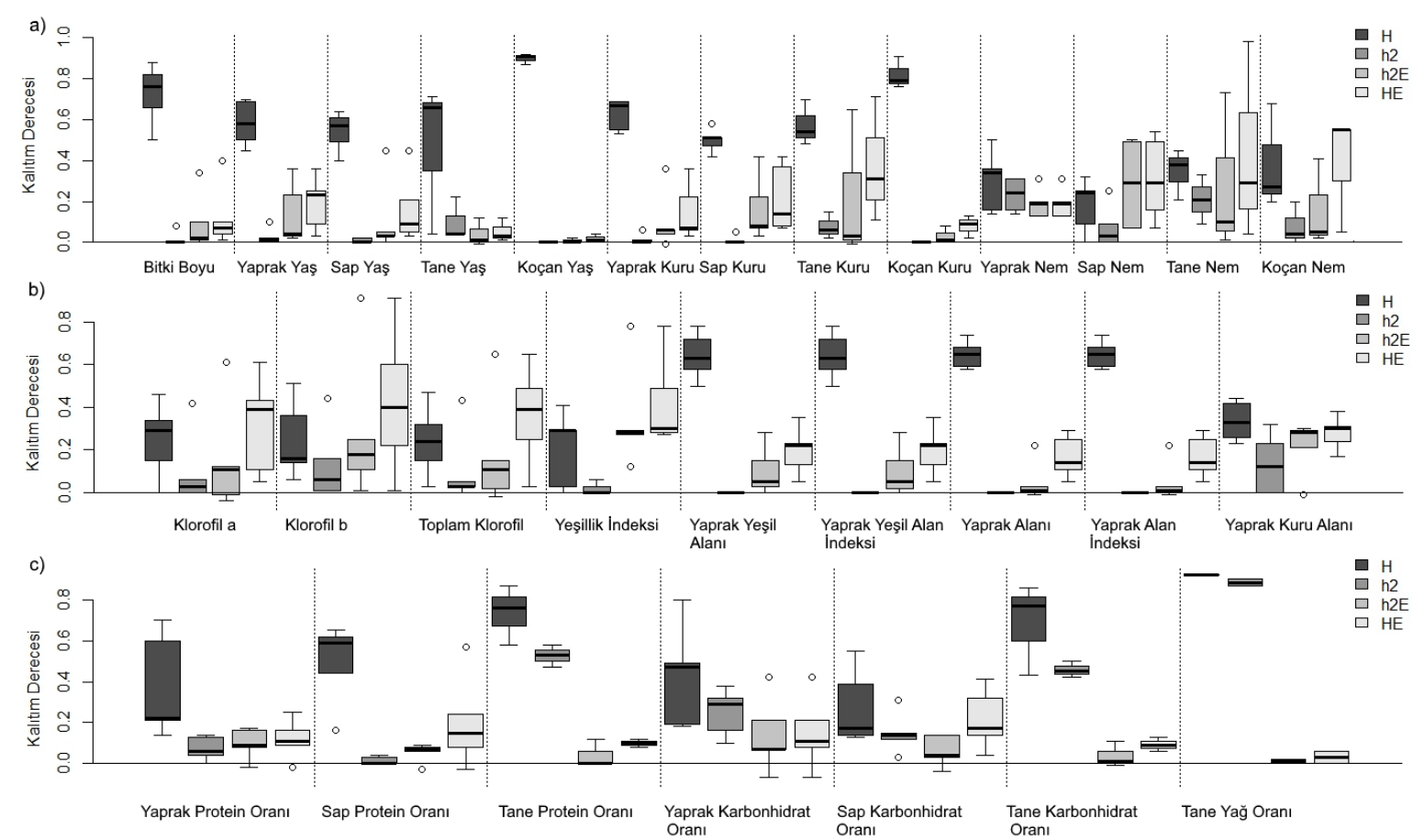

Şekil 4. Bitkisel özellikler (a), fizyolojik özellikler (b) ve kalite özellikleri (c) için kalıtım derecesi değerlerinin değişimi.

Figure 4. Variation of heritability values for plant traits (a), physiological traits (b) and quality traits (c). 
etkileşimleri yüksek bulunmuş, bu durum söz konusu özelliklerin çevresel etkilerden yüksek oranda etkilendiğini ortaya koymuştur. Nitekim nem oranı ile ilgili ölçümlerde geniş ve dar anlamda kalıtım derecesinin düşük bulunması $(<0.50)$ bu durumu doğrulamaktadır (Şekil 4a).

Fizyolojik özelliklerden yaprak rengi ile ilişliki olan pigment içerikleri ve yeşillik indeksinde geniş anlamda kalıtım derecesinin çevre ile olan etkisi nispeten yüksek bulunmuştur (Şekil 4b). Yaprak kuru alanı dışında kalan yaprak büyümesine ilişkin özelliklerde ise geniş anlamda kalıtım derecesi 0.60 'ın üzerinde bulunmuştur (Şekil 4b). Yaprak kuru alanında ise hesaplamaların tamamı 0.50'nin altındadır.

Kalite özelliklerine ilişkin yapılan hesaplamalara ait sonuçlar, tane yağ içeriğinin hem geniş $(\mathrm{H})$ hem de dar anlamda kalıtım derecesinin $\left(\mathrm{h}^{2}\right)$ çok yüksek olduğunu göstermiştir. Rosulj ve ark. (2002) yağ oranı için yapılan seleksiyon çalışmasında başlangıç materyalinde yağ oranı için kalıtım derecesini \% 70'in üzerinde bulmuşlardır. Araştırmamızda kullanılan materyalin yarısı yüksek yağlı IHO genotipleri ile ilişkili materyallerdir. Yağ oranı için kalıtım derecesinin yüksek bulunmuş olması bu sebepledir. Kalıtım derecelerinin yüksekliği dikkate alındığında yağ oranını tane protein içeriği ve tane karbonhidrat içeriği izlemiştir. Yaprak ve sapta protein ile karbonhidrat içeriklerine ait kalıtımda genetik etkinin kısmen düşük paya sahip olduğu anlaşılmışır (Şekil 4c). Bununla birlikte yaprak protein ve karbonhidrat içeriği için hesaplanan geniş anlamda kalıtım derecesinde önemli bir varyasyon olduğu dikkat çekmektedir (Şekil 4c).

Çalışmada kalıtım derecelerinin ESG'lere göre değişimi her tarihte yalnızca bir değer hesaplandığından grafik üzerinde gösterilememiştir. Ancak kalıtım dereceleri ile ilgili grafiklerde her bir hesaplamaya ait değişim görülebilmektedir. İncelenen çoğu özellikte, geniş anlamda kalıtım derecesi başta olmak üzere önemli varyasyonların olduğu dikkat çekmektedir. Bu durum toplam varyans içerisindeki genotipik payın vejetasyon süresince önemli değişimler gösterdiğine işaret etmektedir.

\subsection{Gen Etkileri}

Heterosise neden olan gen etkilerinin grafiksel olarak gösterimi polar grafikler ile Şekil 5 'te gösterilmiştir. İncelenen bitkisel özelliklerden büyük kısmının değişiminde pozitif yönde üstün dominans gen etkilerinin rol oynadığı görülmektedir (Şekil 5a). Benzer şekilde fizyolojik özelliklerle ilgili hibritlerin ebeveynlerden farklılaşması pozitif yönde olmuş ve üstün dominans gen etkilerinin kontrolü ile bu farklılıkların oluştuğu anlaşılmıştır (Şekil 5b). İncelenen tane kalite özelliklerinde negatif yönde üstün dominans ve dominant gen etkilerinin hibrit ve ebeveyn farklılıklarında etkili olduğu anlaşılır iken, bazı özelliklerin değişiminde eklemeli gen etkilerinin rol oynadığ saptanmıştır (Şekil 5c). Bu özelliklerde intermediyer kalıtımın varolduğu anlaşılmaktadır. Yapılan önceki araştırmalarda verim ve bitkisel özelliklerde üstün dominans veya k1smi dominans gen etkilerinin baskın olduğu bildirilmiştir (Zare ve ark. 2011). Protein ve yağ oranı gibi kalite özelliklerinde ise eklemeli gen etlikilerinin rol oynadığ yapılan araştırmalarda tespit edilmiştir (Rosulj ve ark. 2002; Watto ve ark. 2009). Araştırmamızda elde edilen sonuçlar bu bulguları destekler niteliktedir.

Gen etkilerinin vejetasyon süresince değişimi de polar grafikler üzerinde izlenebilmektedir (Şekil 5). Her hibrite ait ortalama değerler ve ebeveyn verileri üzerinden hesaplanan değerlerin vejetasyon dönemlerine göre değişimleri farklı renklerle ifade edilmiştir. Polar grafikler üzerindeki sembollerin ve renklerin dağılımları dikkate alındığında, bitkisel özellikler ile fizyolojik özelliklerin büyük kısmında etkili olduğu saptanan üstün dominans gen etkilerinin gözlem alınan dönemlerin büyük kısmında değişim göstermediği anlaşılmaktadır (Şekil 5a). Ne yazık ki polar grafikler üzerinde genotipik farklılıkları göstermek için sembol yetersiz kaldığından grafikler üzerinde söz konusu farklar görülememektedir. Bu nedenle yüksek yağlı ve yüksek proteinli melezlerde heterosise neden olan gen etkilerinin hibritlere göre değişimi konusunda net bir yargıya varmak mümkün olmamıştır. Buna karşın grafiklerde farklı sembollerle gösterilen özellik gruplarındaki değişimler dikkate alınarak nem oranı dışında bitkisel özelliklerin büyük kısmında hem yüksek yağlı hem de yüksek proteinli hibritlerde üstün dominans gen etkilerinin rol oynadığı anlaşılmaktadır (Şekil 5a). Benzer şekilde fizyolojik özelliklerde de yüksek yağlı ve yüksek proteinli hibritlerde gen etkilerinin benzer olduğu (Şekil $5 b$ ), buna karşın kalite özelliklerinde melez kombinasyonlar arasında önemli bir varyasyon olduğu görülmektedir (Şekil 5c).

Çalışmada elde edilen bulgulara göre, \% 50'si saf hatlardan $\%$ 50'si hibrit kombinasyonlardan oluşan bir popülasyonda incelenen özelliklerde ortaya çıkan heterosisin dominans gen etkilerinin kontrolünde olduğu anlaşılmıştır. Çalışmada ele alınan özelliklerin büyük kısmında heterosisin ortaya çıkışı ana hattın özelliklerine göre şekillenmiştir. Buna karşın aynı ana hattın farklı babalar ile melezlenmesi sonucu elde edilen melezlerde farklılıklar gözlenmiş olması baba hattın da önemli bir etkiye sahip olduğunu göstermiştir. Bu bulgulara dayanarak gen etkilerinin oluşumunda paternal ve maternal etkilerin özelliklere göre değişim gösterdiği söylenebilir. Ayrıca vejetasyonun farkl1 dönemlerinde heterosise neden olan gen etkilerinin bazı özelliklerde önemli değişimler gösterdiği anlaşılmıştır.

\section{Sonuç}

Dönemsel ölçümler ve hesaplamalar neticesinde, vejetasyon süresince özel tip hibritlerin ebeveynlerine göre farklılaşmasına neden olan genlerin fonksiyonel olarak hangi dönemlerde aktif hale geldiği belirlenmiştir. Bu bulgulara göre bitkisel özelliklere ilişkin genlerin vejetasyonun tüm evrelerinde fonksiyonel olduğu, buna karşın tane kalite özellikleri ve yaprak pigment içeriklerine ilişkin genlerin ifade dönemlerinde değişimler olduğu saptanmıştır. Bitkisel özelliklerden bitki boyu, yeşil ve kuru ağırlıklar ile yaprak alanının bütün ölçümlerde pozitif yönlü heterosise sahip olduğu görülmüştür. Nem oranında ise heterosis değeri düşük bulunmuştur. Fizyolojik özelliklerden yaprak alanı ile ilgili özellikler yüksek düzeyde pozitif heterosise sahip olurken, klorofil içeriği ve yeşillik karakterlerine ilişkin ölçümlerde heterosis değerleri vejetasyonun farklı evrelerinde değişim göstermiştir. Nem içeriği ve yaprak pigment içeriği ile yeşillik karakterleri dışındaki tüm özelliklerde geniş anlamda kalıtım derecesi yüksek bulunmuştur. Özel tip misırların kullanıldığı bu araştırmada en yüksek kalıtım derecesi tane yağ, protein ve karbonhidrat içeriğinde hesaplanmıştır. $\mathrm{Bu}$ durum kalite özelliklerine yönelik olarak 1slah edilen ebeveynlerin incelenen özelliklerle ilgili kalıtım derecelerine etkisini ortaya koymaktadır. Yaprak ve sap kalite özelliklerinde tane içeriğine ilişkin özelliklere göre heterosis değerinin düşük olduğu görülmüştür. İncelenen özelliklerin büyük kısmında heterosisin üstün dominans etkilerle ortaya çıktığı görülmüştür. Özel tip mısır geliştirme amacıyla yürütülecek çalışmalarda, çalışmızda tespit ettiğimiz 1slah parametrelerindeki değişimin dikkate alınmasında yarar vardır. 
a)
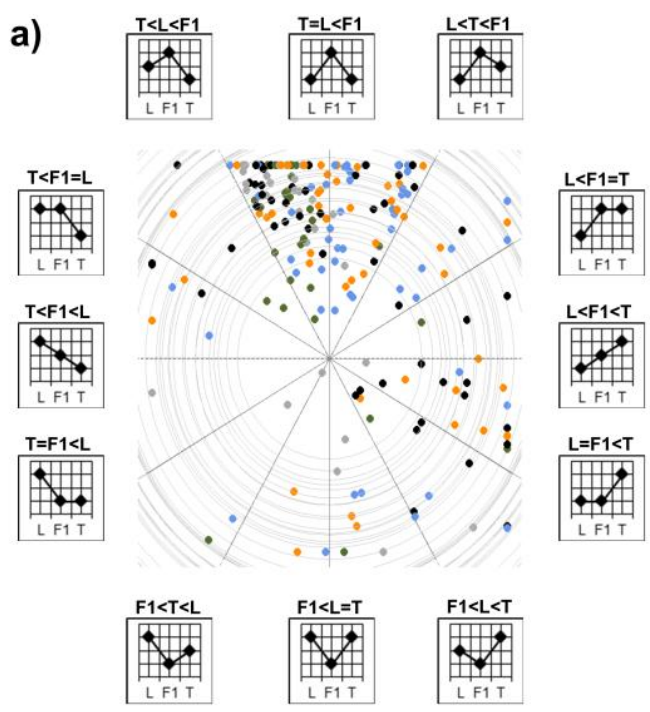

c)
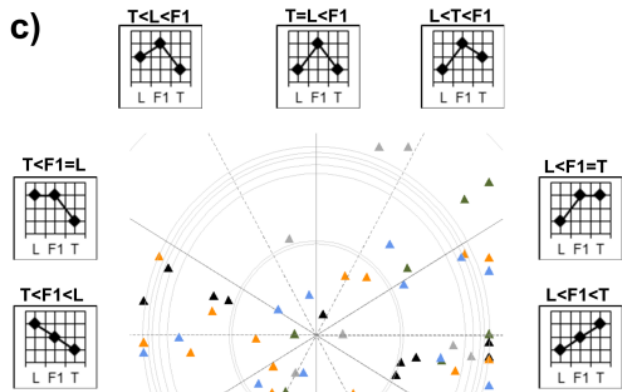

$\triangle \Delta$
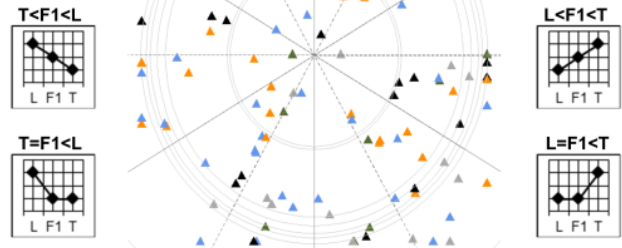

$\Delta /$
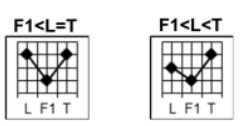

b)
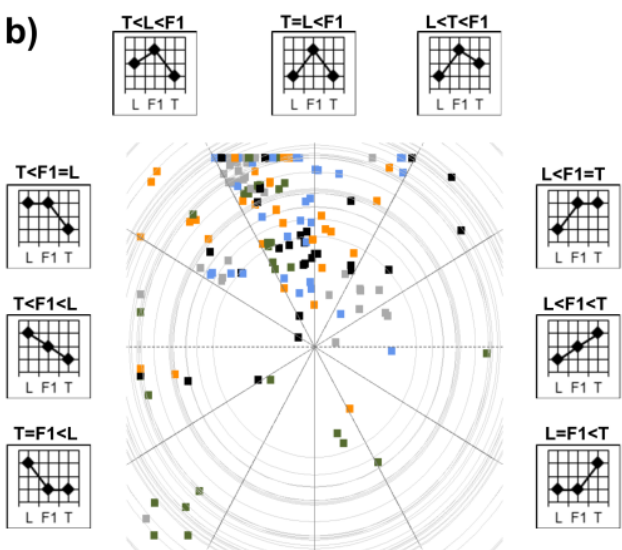

.

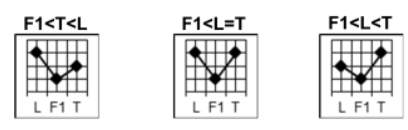

d)
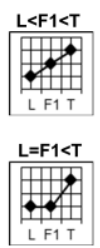

)
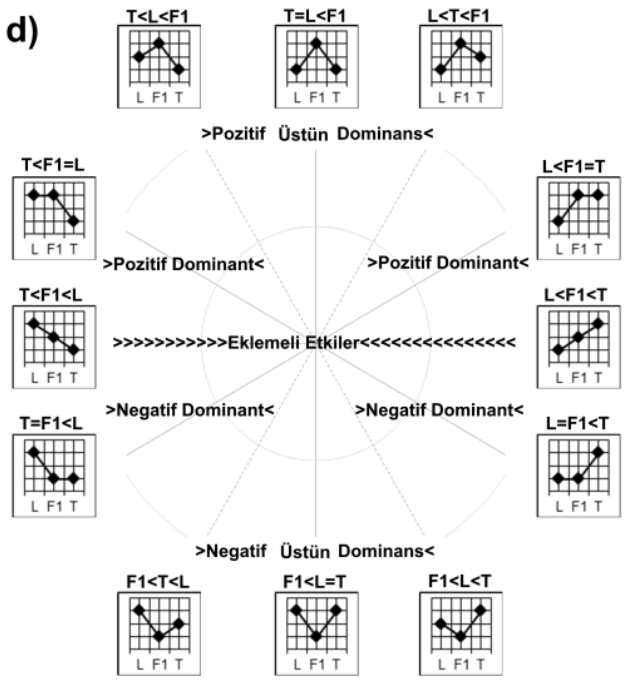

Şekil 5. Bitkisel (a), fizyolojik (b), kalite özellikleri (c) için heterosise neden olan gen etkilerinin polar grafikler üzerinde gösterimi ile gen etkilerine

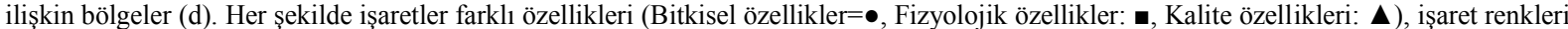
(ESG1:Yeşil, ESG2:Gri, ESG3:Siyah, ESG4:Turuncu, ESG5:Mavi) ise farklı ESG’lere ait hesaplamaları göstermektedir.

Figure 5. Representation of gene effects causing heterosis to physiological (b) quality traits (c) and regions related with gene effects (d) on the polar graphs. Signs showed different characteristics (vegetable properties $=\bullet$, physiological properties: $\mathbf{n}$, quality properties: $\mathbf{\Delta}$ ), and sign colors (ESG1: Green, ESG2: Gray, ESG3: Black, ESG4: Orange, ESG5: Blue) indicates the values for different ESGs.

\section{Teşekkür}

Çalışmanın yürütülmesi için BAP 2011/56 nolu proje ile destek sağlayan Çanakkale Onsekiz Mart Üniversitesi Bilimsel Araştırmalar Komisyonu'na teşekkür ederiz.

\section{Kaynaklar}

Bakr EM (2005) A new software for measuring leaf area, and area damaged by Tetranychus urticae Koch. Journal of Applied Entomology 129(3): 173-175.

Bekele A, Rao TN (2013) Heterosis study for grain yield, protein and oil improvement in selected genotypes of maize (Zea mays L). Journal of Plant Sciences 1(4): 57-63.

Chen G, Zhu Z, Zhang F, Zhu J (2012) Quantitative genetic analysis station for the genetic analysis of complex traits. Chinese Science Bulletin 57(21): 2721-2726.

Gardner CO (1963) Estimation of genetic parameters in cross-pollinated plants and their implications in plant breeding. Statistical Genetics and Plant Breeding, NASNRS Washington D. C. Publication, 982: $228-234$.

Hallauer AR, Miranda JB (1981) Quantitative genetics in maize breeding. Iowa St. Univ. Press, Ames, IA.

Hiscox JD, Israelstam GF (1979) A method for the extraction of chlorophyll from leaf tissue without maceration. Canadian Journal of Botany 57: 1332-1334.

Lisec J, Römisch-Margl L, Nikoloski Z, Piepho H-P, Giavalisco P, Selbig J, Gierl A, Willmitzer L (2011) Corn hybrids display lower metabolite variability and complex metabolite inheritance patterns. The Plant Journal 68: 326-336.

Mahmood S, Malik SI, Hussain M (2016) Heterosis and combining ability estimates for ear traits and grain yield in maize hybrids. Asian J Agri Biol. 4(4): 91-98.

Mittelmann A, Miranda-Filho JB, Monterio de Lima GJJ, Hara-Klein C, Tanaka RT (2003) Potential of the ESA23B Maize population for protein and oil content Improvement. Scientia Agricola 60(2): 319-327. 
Oliveira JP, Chaves LJ, Duarte JB, Oliveira-Ribeiro K, Brasil EM (2006) Heterosis for oil content in maize populations and hybrids of high quality protein. Crop Breeding and Applied Biotechnology 6: 113-120.

Orhun GE (2010) Misırda (Zea mays) yağ kalitesi ve tane verimi ile ilgili özelliklerde kalıtım analizleri, Doktora Tezi, Namık Kemal Üniversitesi, Fen Bilimleri Enstitüsü, $192 \mathrm{~s}$.

R Development Core Team (2012) R: A language and environment for statistical computing. R Foundation for Statistical Computing, Vienna, Austria. ISBN 3-900051-07-0, URL http://www.Rproject.org.

Rood SB, Major DJ (1981) Diallel analysis of leaf number, leaf development rate, and plant height of early maturing maize. Crop Science 21: 867-873.

Rosulj M, Trifunovic S, Husic I (2002) Nine cycles of mass selection for increasing oil content in two maize (Zea mays L) synthetics. Genetics and Molecular Biology 25: 449-461.

Römisch-Margl L, Spielbauer G, Schützenmeister A, Schwab W, Piepho H.P, Genschel U, Gierl A (2010) Heterotic patterns of sugar and amino acid components in developing maize kernels. Theorotical Applied Genetics 120: 369-381.

Schön CC, Lee M, Melchinger AE, Guthrie WD, Woodman WL (1993) Mapping and characterization of quantitative trait loci affecting resistance against second-generation European corn borer in maize with the aid of RFLPs. Heredity 70: 648-659.

Shanthi P, Satyanarayana E, Reddy GJM (2002) Genetic studies for grain yield and oil improvement in maize. Research on Crops 3(3): 588-591.

Swanson-Wagner RA, Jia Y, DeCook R, Borsuk LA, Nettleton D, Schnable PS (2006) All possible modes of gene action are observed in a global comparison of gene expression in a maize F1 hybrid and its inbred parents. Proceedings of National Academy of Sciences USA, 103: 6805-6810.
Tollenaar M, Ahmadzadeh A, Lee EA (2004) Physiological basis of heterosis for grain yield in maize. Crop Science 44: 2086-2094.

Veita RA, Waiman D (2010) Exploring the mechanistic bases of heterosis from the perspective of macromolecular complexes. The FASEB Journal 25: 1-7.

Watto FM, Saleem M, Ahsan M, Sajjad M, Ali W (2009) Genetic analysis for yield potential and quality traits in maize (Zea mays L.). American-Eurasian Journal of Agriculture Environment Science 6(6): 723-729.

Werle AJS, Ferreira FRA, Pinto RJB, Mangolin CA, Scapim CA, Gonçalves LSA (2014) Diallel analysis of maize inbred lines for grain yield, oil and protein content. Crop Breeding and Applied Biotechnology 14: 23-28.

Wyss CS, Czyzewicz JR, Below FE (1991) Source-sink control of grain composition in maize strains divergently selected for protein concentration. Crop Science 31: 761-766.

Yusuf M, Ado SG, Ishiyaku MF (2009) Heterosis in single crosses of quality protein maize inbred lines, African Crop Science Conference Proceedings Vol. 9. pp. 439-445.

Zare M, Choukan R, Bihamta MR, Majidi Heravan E, Kamelmanesh MM (2011) Gene action for some agronomic traits in maize (Zea mays L.). Crop Breeding Journal 1(2): 133-141.

Zhu J (2003) Diallel analysis for an additive-dominance model with genotype-by- environment interaction effects. In: Kang, M.S., Ed., Handbook of formulas and software for plant geneticists and breeders, Food Products Press, The Haworth Reference Press, Oxford, pp. 39-50. 